\title{
WHEN THE UNION HURTS THE WORKERS: A Positive ANALYSIS OF IMMIGRATION POLICY
}

\author{
GiORGIO BELLETTINI \\ CARLOTTA BERTI CERONI
}

CESIFO WORKING PAPER No. 1421

CATEGORY 4: LABOUR MARKETS

MARCH 2005

An electronic version of the paper may be downloaded

- from the SSRN website:

www.SSRN.com

- from the CESifo website:

www.CESifo.de 


\title{
WHEN THE UNION HURTS THE WORKERS: A Positive ANALYSIS OF IMMIGRATION POLICY
}

\begin{abstract}
This paper studies the determinants of immigration policy in an economy with entrepreneurs and workers where a trade union has monopoly power over wages. The presence of the union leads a benevolent government to implement a high level of immigration and induces a welfare loss not only from an aggregate point of view, but even from the point of view of workers. In the politico-economic equilibrium where interest groups lobby for immigration, we show the condition under which workers are no longer hurt by the presence of the union.
\end{abstract}

JEL Code: F22, J51, J61.

\author{
Giorgio Bellettini \\ Department of Economics \\ University of Bologna \\ Piazza Scaravilli 2 \\ 40126 Bologna \\ Italy \\ bellettini@economia.unibo.it
}

\author{
Carlotta Berti Ceroni \\ Department of Economics \\ University of Bologna \\ Piazza Scaravilli 2 \\ 40126 Bologna \\ Italy \\ bceroni@economia.unibo.it
}

We would like to thank seminar participants at the University of Bologna, ASSET 2004 conference, SED 2004 conference, and in particular Andrea Moro for useful comments on previous versions of this paper. The first author has worked on the current version of the paper while he was visiting CES, of which he acknowledges the very helpful support. 


\section{Introduction}

The number of immigrants entering OECD countries labor markets has been increasing impressively in recent years. Between 1965 and 2000 the migrant stock as a percentage of the local population more than doubled in North America, rising from 6 to 13 per cent, and almost tripled in Western Europe, rising from 3.6 to 10.3 per cent (Hatton and Williamson [13]).

Large migrants inflows put immigration at the center of the political debate in many countries and arouse concern in the general public. In the 1997 Eurobarometer survey, migration turns out to be one of the three most significant issues. According to a 1995 international survey (O' Rourke and Sinnott [15]), answers to the question whether immigration should be decreased ranged between "reduce a little" and "reduce a lot" in Germany, Britain and the US, three big immigration countries.

Economic reasons play an important role in determining attitudes toward immigration. As the educational level of immigrants is typically lower than in the local population, hostility towards immigrants is generally stronger among the unskilled worker who fear negative effects in terms of lower wages and/or higher unemployment. Instead, skilled workers and capital owners tend to support migration as they expect larger returns to human and physical capital.

Immigration policy reflects these conflicting interests as the outcome of a political process involving the government, social parties, political parties and activists.

When the policymaker is relatively insulated from pressures by social groups, immigration can be seen as a regulatory sphere with the government implementing policies in the national interest ${ }^{1}$.

Often, however, migration policy is the realm of special interests. According to political scientists (see Freeman [9]), an important mode of immigration politics in Western democracies is client politics in which policymakers interact intensively out of public view

\footnotetext{
${ }^{1}$ The autonomy of policymakers from pressure groups depends on several institutional features such as the locus of decision making (administration, cabinet, parliament) and the license of courts to repeal government decisions.
} 
with groups who have a well-defined stake in migration (e.g. employers), while main political parties seek to avoid open conflict over migration issues. This tends to generate expansionary migration policy as those who benefit from migration prevail over less organized or less intense opposition.

When those who oppose migration gain additional voice, interest groups politics prevails where organized social groups with well-defined and conflicting interests over migration struggle to influence the policymaker in their favor ${ }^{2}$. In this case, the representation of (unskilled) workers' interests in policymaking clearly depends on the presence of organized and strong trade unions, as these institutions play an active political role which goes beyond wage bargaining in many countries.

Although it is widely recognized that immigration policy is the result of the composition of different interests, there exist surprisingly few theoretical economic models which provide a positive analysis of immigration policy that explicitly takes into account the influence of lobbies on government's behavior (to the best of our knowledge, only Amegashie [1] and Epstein and Nitzan [7]).

In this paper we try to fill this gap. We use a political economy approach to study the determination of migration policy and its welfare and distributional consequences in an economy where agents have conflicting economic interests over migration and the labor market is not competitive due to the presence of a trade union.

As the union pushes wages above the Walrasian level, unemployment occurs in equilibrium. Entrepreneurs (skilled workers) support migration as this reduces wages and increases employment and profits while (unskilled) workers would rather restrict immigrants inflows.

Following the above discussion, we see policy choices over migration as determined by

\footnotetext{
${ }^{2}$ Another cathegory proposed by Freeman is populism which is described as a situation where entrepreneurial politicians (e.g. Le Pen in France, Buchanan in the US, Bossi in Italy) engage in the mobilization of resentment among groups whose members believe that they are adversely affected by immigration as well as of nationalist sentiments and xenophobia. If succesful, populism may represent a transitional mode from client to interest group politics as opponents of immigration gain additional voice. Otherwise it will be a transitory phenomenon with limited impact on immigration policies.
} 
the influence of these conflicting interests and government's ability to compose them. Our analysis identifies the presence of the trade union as a decisive factor in determining the outcome of the political process and the properties of the politico-economic equilibrium.

We first investigate the situation where the level of immigration is determined by a benevolent government to maximize natives' welfare (regulatory politics). The presence of the union in wage determination leads the government to implement a level of immigration higher than the one which would arise with a competitive labor market. This is due to the fact that, anticipating that the union will generate an efficiency loss by pushing wages above the Walrasian level, the government increases the immigration level in order to reduce wages and increase employment and profits.

The optimal response of the government to the union's behavior generates an interesting result in terms of welfare. In particular, we show that the presence of the union induces a welfare loss not only from an aggregate point of view, but even from the point of view of workers who would be better off in a competitive labor market. This happens as the higher level of immigration pushes the wage rate below the level that would prevail in a competitive labor market where the level of immigration chosen by the government would be lower.

These results would inevitably question workers' support for the union. However, when the analysis is extended to allow for the direct influence of interest groups the outcome may be radically different and we can provide an explanation for why trade union behavior can increase workers' welfare.

Although several political actors may represent workers' stances in immigration policy ${ }^{3}$, we take it as a fact that the effectiveness of workers' voice in the political process is strongly enhanced by the presence of a powerful trade union. Thus, if interest groups pressures have sufficiently high weight in government decisions, workers are no longer necessarily hurt by union behavior and may benefit from the presence of the union (interest groups politics). Intuitively, this has to do with the fact that, without the union, the government would

\footnotetext{
${ }^{3}$ As discussed above the affirmation of populist movements may increase the voice of those who oppose migration, including unskilled workers.
} 
respond excessively to political pressures of entrepreneurs and set a high immigration level, thereby triggering a large decline in wages (client politics).

To formalize the lobbying process we use the common agency framework pioneered by Bernheim and Whinston [5], and applied to different economic problems by authors such as Bellettini and Ottaviano [3], Dixit, Grossman and Helpman [6], Grossman and Helpman [11], Persson [16]. Solving for the Truthful Perfect Equilibrium of the lobbying game between the government, the lobby of entrepreneurs and the lobby of workers, we characterize the equilibrium level of immigration chosen by the government and the equilibrium contributions of the two lobbies.

This analysis allows us to derive our welfare results by focusing on a key parameter, which is the relative weight of social welfare relative to lobbies' contribution in the objective function of the government. In particular, we show that there exists a threshold level of this parameter, such that, for any level below this threshold, workers benefit from the presence of the union.

As we wrote above, this paper is related to the few existing studies (see Amegashie [1] and Epstein and Nitzan [7]) which analyze a model of the political economy of immigration based on the activity of lobbying groups. In these papers, however, no attention is paid to the role of the union in the process of wage determination and to the interaction between the labor market equilibrium and the political choice of immigration.

The remaining of the paper is organized as follows. Section 2 introduces the economic model. Section 3 compares the level of immigration chosen by a benevolent social planner when the labor market is unionized with the level of immigration chosen by the social planner when the labor market is competitive. Section 4 studies the politico-economic equilibrium with lobbies and Section 5 provides a numerical example. Section 6 concludes.

\section{The economic model}

Consider a one-good economy where agents differ with respect to their source of income and their country of birth. In particular, we assume that there are $H$ domestic entrepreneurs, $N$ domestic workers, and $I$ immigrant workers. Each entrepreneur owns a firm. The firm 
is endowed with technology:

$$
y=l^{\alpha}
$$

where $l$ represents employment, and $y$ is output.

Agents derive utility from consumption which is equal to profit income $\pi$ for entrepreneurs and wage income $w$ for workers. Preferences are represented by a CRRA utility function:

$$
U(c)=\frac{c^{1-\delta}}{1-\delta}
$$

where $c$ represents consumption and $\delta>1$ is the coefficient of relative risk aversion. ${ }^{4}$

The labor market is non-competitive. The wage rate is set by a monopolistic union to solve the following problem:

$$
\max _{w}\left(w-w^{c}\right)^{\theta}[H l(w)]^{1-\theta}
$$

where $w^{c}=\alpha\left(\frac{N+I}{H}\right)^{\alpha-1}$ is the Walrasian wage. Employment is determined by firms according to labor demand, which is isoelastic with respect to wage. Denoting with $\sigma$ the elasticity of labor demand we have $\sigma=(1-\alpha)^{-1}$.

Given total labor supply $N+I$, the union seeks to raise the wage above the level that the workers would earn in the absence of the union, that is the Walrasian level $w^{c}$. Moreover, the union takes into account the employment loss triggered by the increase in wage. The parameter $\theta$ denotes the weight of the wage gain relative to employment ${ }^{5}$.

The maximization problem of the union yields:

$$
w=\Delta w^{c}
$$

where $\Delta \equiv \frac{(1-\theta) \sigma}{(1-\theta) \sigma-\theta}$. Employment is thus equal to:

$$
l=\Delta^{-\sigma}\left(\frac{N+I}{H}\right)
$$

\footnotetext{
${ }^{4}$ As we will see in the next section, $\delta>1$ is necessary and sufficient for the second order condition of the maximization problem of the government to be satisfied.

${ }^{5}$ Our objective function of the union is used in a different context by Irmen and Wigger [14]. Alternative specifications of union's objective functions are discussed, among others, by Booth [4] and Farber [8].
} 
Since $\Delta>1$ the union raises the wage above the Walrasian level and creates unemployment. In what follows, we will assume that the unemployed can attain a consumption level equal to $b \leq w$.

The number of immigrants negatively affects the union wage rate through its negative effect on the reference level $w^{c}$. While the decline in the wage rate increases employment and profits, the probability of being employed, which is given by $\frac{H l(w)}{N+I}=\Delta^{-\sigma}$, is independent of the number of immigrants (and of labor supply in general) so that workers are certainly hurt by a higher immigration level. Thus, a conflict of interests emerges between workers and entrepreneurs that goes through the negative effect of immigration on the Walrasian wage rate.

\section{The optimal level of immigration}

Let us analyze what would be the level of immigration chosen by a benevolent government in order to maximize the welfare of natives. As for the timing of the relevant choices, we will consider the case where the government chooses the level of immigration before wages are determined. Clearly, the rational government anticipates that the wage rate will be set according to equation (4).

We consider a utilitarian social welfare function:

$$
W=\frac{N}{1-\delta}\left[\frac{H l(w)}{N+I} w^{1-\delta}+\frac{N+I-H l(w)}{N+I} b^{1-\delta}\right]+\frac{H}{1-\delta} \pi^{1-\delta}
$$

where $\frac{H l(w)}{N+I}$ is the probability that a worker (domestic or foreign) is employed.

Substituting equations (4) and (5) in (6) and maximizing with respect to $I$ yields:

$$
I^{G}=\left[N\left(\frac{1-\alpha}{\Delta^{\sigma} \alpha H}\right)^{\delta}\right]^{\frac{1}{1-\delta}}-N
$$

where we used $\pi=(1-\alpha) l^{\alpha}$. Note that the second order condition for a maximum is satisfied if and only if $\delta>1$.

When considering an increase in $I$, the benevolent government trades the welfare loss of native workers (due to the decrease of $w$ ) with the gain of entrepreneurs (due to higher $\pi$ ). 
The larger is the wage gap $\Delta$, the higher is $I^{G}$ as the government mitigates the presence of the union by redistributing income to entrepreneurs. Similarly, the higher is $\alpha$, the higher is $w$ relative to $\pi$ and the higher is $I^{G}$. Finally, a larger $N$ and/or a lower $H$ imply a lower $I^{G}$ as $w$ decreases and the weight of workers in the utilitarian welfare function increases.

It is worthwhile to compare the government's solution in the presence of the union with the optimal solution for the government when the labor market is competitive (that is, in the absence of the union). In this case, the level of immigration is chosen to maximize eq. (6) with $w=w^{c}$ and $l=\frac{N+I}{H}$, yielding:

$$
I^{C}=\left[N\left(\frac{1-\alpha}{\alpha H}\right)^{\delta}\right]^{\frac{1}{1-\delta}}-N
$$

Notice that $I^{C}<I^{G}$, so that in the competitive case the government chooses a level of immigration which is lower than in the non-competitive case. The presence of the union induces the government to redistribute income in favor of the owners of the firms, thereby increasing immigration. ${ }^{6}$

With regard to welfare, we can state the main result of this section:

Proposition 1 When immigration is chosen by a benevolent government, aggregate welfare and the expected utility of workers are lower in the presence of the union than with no union. On the contrary, entrepreneurs are better off with the union.

Proof. Plugging equations (7) and (8) in (6) and letting $b=w$, we get $W\left(I^{G}\right)<$ $W\left(I^{C}\right)$ if and only if:

$$
\alpha(\Delta-1)>(1-\alpha)\left(1-\Delta^{-\alpha \sigma}\right)
$$

which is always satisfied for $\Delta>1$. Both the left-hand side and the right-hand side term in equation (9) are increasing with $\Delta$ and tend to zero as $\Delta \rightarrow 1$. However, the derivative with respect to $\Delta$ of the left-hand side (which is equal $\alpha$ ) is larger than that

\footnotetext{
${ }^{6}$ In a different model, Schmidt, Stilz and Zimmermann [?] also consider the use of immigration policy by the government as anti-union policy for possible welfare improvements. Differently from our analysis, they do not explicitly compare welfare levels with and without the union and do not analyze whether the existence of the union can hurt workers.
} 
of the right-hand side, equal to $\alpha \Delta^{-1-\alpha \sigma}$. Obviously, for any $b<w, W\left(I^{G}\right)<W\left(I^{C}\right)$ is a fortiori satisfied. Plugging equations (7) and (8) in $w$ and $w^{c}$ it is immediate to verify that $w\left(I^{G}\right)<w^{c}\left(I^{C}\right) \Leftrightarrow \Delta^{\frac{1}{\delta-1}}>1$ which is true as $\Delta>1$ and $\delta>1$. Thus, workers are necessarily worse off with the union. Finally, notice that $\pi\left(I^{C}\right)=(1-\alpha)\left[\frac{N}{H}\left(\frac{1-\alpha}{\alpha}\right)^{\delta}\right]^{\frac{1}{1-\delta}}$ and $\pi\left(I^{G}\right)=(1-\alpha)\left[\frac{N}{H \Delta^{\sigma}}\left(\frac{1-\alpha}{\alpha}\right)^{\delta}\right]^{\frac{1}{1-\delta}}$ so that $\pi\left(I^{G}\right)>\pi\left(I^{C}\right)$.

Surprisingly, when immigration is optimally set by the government, the presence of the union benefits the entrepreneurs at the expense of the workers. As we have already discussed, when the union sets the level of wages, the government reacts by increasing immigration. In equilibrium, this reduces wages below the competitive level so that workers are necessarily hurt. On the contrary, entrepreneurs benefit from increased overall employment, and the net effect on social welfare is negative.

To understand what is necessary for this result to hold, suppose that, in the presence of the union, the level of immigration chosen by the government were equal to $I^{\prime}$ such that $w\left(I^{\prime}\right)=\Delta w^{c}\left(I^{\prime}\right)=w^{c}\left(I^{C}\right)$. In words, the government would increase immigration up to a point where the unionized wage would be exactly equal to the wage with no union. The first derivative of the government objective function with respect to $I$ calculated at $I^{\prime}$ can be written as:

$$
\left[\Delta^{-\sigma} N u^{\prime}\left(w\left(I^{\prime}\right)\right)-H u^{\prime}\left(\pi\left(I^{\prime}\right)\right) \alpha \sigma \frac{\pi\left(I^{\prime}\right)}{w\left(I^{\prime}\right)}\right] \frac{d w}{d I} \geq 0
$$

Taking into account that wages and profits at $I^{\prime}$ are by definition equal to those prevailing in the Walrasian equilibrium, we can rewrite the above inequality as:

$$
\Delta^{-\sigma} N u^{\prime}\left(w^{c}\left(I^{C}\right)\right)-H u^{\prime}\left(\pi^{c}\left(I^{C}\right)\right) \alpha \sigma \frac{\pi^{c}\left(I^{C}\right)}{w^{c}\left(I^{C}\right)} \leq 0
$$

which holds as strict inequality since by definition $I^{C}$ is such that:

$$
N u^{\prime}\left(w^{c}\left(I^{C}\right)\right)-H u^{\prime}\left(\pi^{c}\left(I^{C}\right)\right) \alpha \sigma \frac{\pi^{c}\left(I^{C}\right)}{w^{c}\left(I^{C}\right)}=0
$$

Thus, the optimal $I$ must be larger than $I^{\prime}$ and the wage rate must be lower than $w^{c}\left(I^{C}\right)$. Intuitively, the existence of unemployed workers whose exogenous income is unaffected by immigration decreases the weight of workers in the social welfare function from 1 to $\Delta^{-\sigma}$. As a consequence, the government can achieve higher utility by redistributing 
income further in favor of the agents whose weight is unaffected by unemployment, that is the entrepreneurs.

Notice the existence of a fixed "mark up" of the unionized wage over the Walrasian wage and of a isoelastic labor demand are the features of our model which play a crucial role in the result. In many models of union behavior, the unionized wage is a fixed mark up over an exogenous alternative income (typically, the unemployment benefit) so that the unionized wage is constant and independent of labor supply (and thus of immigration levels). In our framework, to formalize the conflict of interests between workers and capitalists, we need a negative relationship between the unionized wage and the level of immigration, which goes through the negative effect of immigration on the Walrasian wage. $^{7}$

Our findings highlight the important consequences of considering the level of immigration $I$ as optimally chosen by the government. Indeed, a different result arises if, starting from the competitive equilibrium, a union is introduced while keeping the level of immigration fixed at $I^{C}$. In this case, the union increases wages above the Walrasian level, and, if the utility when unemployed is not too small, it increases workers' welfare at the expense of entrepreneurs. More specifically, we can write:

Proposition 2 Let $I=I^{C}$. Then, the introduction of the union decreases social welfare. If and only if $b>\underline{b}=\alpha\left[\frac{N}{H}\left(\frac{1-\alpha}{\alpha}\right)^{\delta}\right]^{\frac{1}{(\delta-1) \sigma}}\left(\frac{1-\Delta^{-\sigma}}{1-\Delta^{1-\delta-\sigma}}\right)^{\frac{1}{\delta-1}}$, the union increases the expected utility of workers.

Proof. (i) Let $W^{u}\left(I^{C}\right)$ be the level of social welfare when the labor market is unionized

\footnotetext{
${ }^{7}$ Another approach would be to identify the alternative income with the competitive wage rate assuming that the union coverage is not complete. However, under fairly general assumptions, we have shown that, in a right-to-manage framework, the union cannot do better than set the wage at the competitive level in the unionized sector so that no wage gap emerges between the unionized and non-unionized sector.

In Appendix 3, we show that similar results to those of our paper can be obtained in an efficient bargaining model.
} 
and $I=I^{C}$. Then:

$$
W^{u}\left(I^{C}\right)<W\left(I^{C}\right) \Leftrightarrow N \alpha^{1-\delta}\left(\frac{N+I^{C}}{H}\right)^{\delta-1}+H(1-\alpha)^{1-\delta}\left(\Delta^{1-\delta}+\Delta^{\alpha \sigma(\delta-1)}-1\right)>0
$$

which is satisfied since $\left(\Delta^{1-\delta}+\Delta^{\alpha \sigma(\delta-1)}-1\right)>0$.

(ii) The expected utility of the representative worker in presence of the union is given by:

$$
W_{w}^{u}=\frac{1}{1-\delta}\left[\Delta^{-\sigma} w^{1-\delta}+\left(1-\Delta^{-\sigma}\right) b^{1-\delta}\right]
$$

Notice that this is larger than $\frac{\left(w^{c}\right)^{1-\delta}}{1-\delta}$ if and only if $b>\alpha\left[\frac{N}{H}\left(\frac{1-\alpha}{\alpha}\right)^{\delta}\right]^{\frac{1}{(\delta-1) \sigma}}\left(\frac{1-\Delta^{-\sigma}}{1-\Delta^{1-\delta-\sigma}}\right)^{\frac{1}{\delta-1}}$.

For any given $I$, the introduction of the union has standard efficiency and redistributive effects. Wages are increased so that unemployment is generated. This reduces social welfare. Workers will be better off provided that the cost of being unemployed is not too large.

Instead, if the government responds optimally to the existence of the union, it will increase the immigration level to $I^{G}$. This allows the government to increase social welfare although it cannot achieve the competitive level. The resulting fall in wages hurt workers, who would be better off without the union.

The welfare loss of workers due to the presence of the union raises the natural question of why workers would deliberately accept membership and provide support for it, rather than get rid of the union and enjoy a higher level of welfare. The next section tackles this issue by investigating the political determination of immigration policy.

\section{The politico-economic equilibrium}

In the welfare analysis that we have conducted so far we have assumed the presence of a benevolent government who sets the immigration level in order to maximize the welfare of the natives.

Often, however, immigration policy is the realm of special interests with lobbies representing entrepreneurs and workers who seek to influence the outcome of the legislative 
process in their favor. Once the immigration level (and, more generally, policies which affect the labor market) has been set by the government, employers and trade unions bargain over wages and employment is determined.

According to this description, the politico-economic equilibrium that we have in mind is the following:

1. The lobbies of entrepreneurs and workers offer contributions to the government conditional on the immigration policy.

2. The government sets the immigration level $I$ taking into account the contributions of the lobbies of entrepreneurs and workers and anticipating how the wage rate will be determined on the labor market.

3. The union sets the wage rate taking $I$ as given and employment is determined by labor demand.

Notice that the lobbies of entrepreneurs and workers do not necessarily correspond to the actors of the bargaining process on the labor market, namely the trade union and the associations of entrepreneurs as conflicting interests on immigration policy may be defended by other political organizations, such as political parties, human rights activists, etc.

It should also be noted that in principle both natives and immigrant workers may be represented in the lobbying activity. In our model, we restrict attention to the case where only natives participate in the lobbying activity. ${ }^{8}$

Following the recent literature pioneered by Bernheim and Whinston [5], we will model the lobbying game as a menu auction game with globally truthful contributions.

In the first stage, the lobby $j \in\{e, w\}$ offers contributions $C_{j}$ that are globally truthful, so that we can write:

$$
C_{j}(I)=\max \left\{0, V_{j}(I)-v_{j}\right\}
$$

\footnotetext{
${ }^{8}$ Notice that the degree of representation of immigrants in the political process is low in many countries.
} 
where $V_{j}$ is the objective function of lobby $j$ and $v_{j}$ is a scalar optimally set by each lobby $j$. The objective functions for the lobby of workers and entrepreneurs are given by:

$$
\begin{aligned}
V_{w} & =\frac{N}{1-\delta}\left[\frac{H l(w)}{N+I} w^{1-\delta}+\left(1-\frac{H l(w)}{N+I}\right) b^{1-\delta}\right] \\
V_{e} & =\frac{H}{1-\delta} \pi^{1-\delta}
\end{aligned}
$$

In the second stage, government chooses $I$ to maximize a weighted average of social welfare and contributions:

$$
I^{*}=\arg \max \left[\lambda W(I)+(1-\lambda) \sum_{j} C_{j}\right]
$$

with $\lambda \in(0,1)$.

Finally, in the third stage, the union sets the wage to maximize equation (3) given the number of immigrants $I$ chosen by the government in the previous stage.

Definition 1 (Truthful Perfect Equilibrium) The contribution schedules $C_{e}^{*}(I), C_{w}^{*}(I)$ and the immigration level $I^{*}\left(C_{e}(\cdot), C_{w}(\cdot)\right)$ form a Truthful Perfect Equilibrium (TPE) if and only if:

(i) for $C_{e}(\cdot)$ and $C_{w}(\cdot), I^{*}\left(C_{e}(\cdot), C_{w}(\cdot)\right)$ is a solution to

$$
\max _{I} \lambda W(I)+(1-\lambda) \sum_{j} C_{j}
$$

(ii) there is no other contribution schedule $C_{e}^{\prime}(I)$ such that

$$
V_{e}\left(I^{\prime}\right)>V_{e}\left(I^{*}\right)
$$

where $I^{*}=I^{*}\left(C_{e}^{*}(\cdot), C_{w}^{*}(\cdot)\right)$ and $I^{\prime}=I^{\prime}\left(C_{e}^{\prime}(\cdot), C_{w}^{*}(\cdot)\right)$ are best response actions to $\left(C_{e}^{*}(\cdot), C_{w}^{*}(\cdot)\right)$ and $\left(C_{e}^{\prime}(\cdot), C_{w}^{*}(\cdot)\right)$ respectively.

(iii) there is no other contribution schedule $C_{w}^{\prime}(I)$ such that

$$
V_{w}\left(I^{\prime}\right)>V_{w}\left(I^{*}\right)
$$

where $I^{*}=I^{*}\left(C_{e}^{*}(\cdot), C_{w}^{*}(\cdot)\right)$ and $I^{\prime}=I^{\prime}\left(C_{e}^{*}(\cdot), C_{w}^{\prime}(\cdot)\right)$ are best response actions to $\left(C_{e}^{*}(\cdot), C_{w}^{*}(\cdot)\right)$ and $\left(C_{e}^{*}(\cdot), C_{w}^{\prime}(\cdot)\right)$ respectively.

(iv) $C_{e}^{*}(\cdot)$ and $C_{w}^{*}(\cdot)$ are truthful strategies with respect to $I^{*}(\cdot)$. 
The existence of the TPE has been established by Bernheim and Whinston [5]. As for the characterization of our TPE, let us assume that $b=\underline{b}$. Then, we can write the following result:

Proposition 3 (The politico-economic equilibrium) The Truthful Perfect Equilibrium of the lobbying game is such that:

(i) $I^{*}=\left[N\left(\frac{1-\alpha}{\Delta^{\sigma} \alpha H}\right)^{\delta}\right]^{\frac{1}{1-\delta}}-N$

(ii) $C_{w}^{*}=\left\{\begin{array}{l}\bar{C}\left(\alpha+\frac{\lambda^{\alpha}-1}{1-\lambda}\right) \quad \text { if } \lambda \geq \Gamma^{\sigma} \\ \bar{C}\left(\frac{1-\alpha}{1-\lambda} \Gamma^{\alpha \sigma}+\frac{\alpha \lambda}{1-\lambda} \Gamma^{-1}+\alpha-\frac{1}{1-\lambda}\right) \quad \text { if } \lambda<\Gamma^{\sigma}\end{array}\right.$

(iii) $C_{e}^{*}=\left\{\begin{array}{c}\bar{C}\left(-\alpha+\frac{\lambda^{1-\alpha}-\lambda}{1-\lambda}\right) \text { if } \lambda \leq \Gamma^{-\sigma} \\ \bar{C}\left(\frac{\alpha\left(\Gamma^{-1}-1\right)-(1-\alpha) \lambda\left(1-\Gamma^{\alpha \sigma}\right)}{1-\lambda}\right) \text { if } \lambda>\Gamma^{-\sigma}\end{array}\right.$

where $\bar{C} \equiv \frac{1}{1-\delta} N^{\alpha} H^{1-\alpha} \Delta^{-\alpha \sigma}(1-\alpha)^{-\delta(1-\alpha)} \alpha^{-\alpha \delta}$ and $\Gamma \equiv \frac{\Delta\left(1-\Delta^{-\sigma}\right)}{1-\Delta^{1-\delta-\sigma}}$

Proof. See Appendix.

As it is well known in the literature following Bernheim and Whinston [5], the solution which arises when all agents are represented in the lobbying process is equivalent to the solution of the benevolent government.

As we have seen in Proposition 1, this solution hurts the workers, who would be better off in the absence of the union. Here, their welfare is even lower than in the case analyzed in the previous section, since they have to pay contributions to the government. Then, the same question of the previous section arises of why should the workers support the union.

The politico-economic equilibrium that we have analyzed in this section can help us to answer this question. Specifically, as discussed in the Introduction, we argue that, without the union, workers lose voice in the political process and their ability to influence government policy is reduced. Thus, although the union can be detrimental to workers from a purely economic point of view, it could nonetheless be beneficial for them in the political arena.

To formalize this idea, let us consider the extreme case where, in the absence of the union, workers have no voice at all so that government's decisions are influenced by entre- 
preneurs' lobbies only. In this case, the objective function of the government becomes:

$$
G\left(I, C_{e}\right)=\lambda W(I)+(1-\lambda) C_{e}
$$

Notice that, in the absence of the union, the labor market is competitive, $w=w^{c}$ and there is full employment. Thus, under the assumption of truthful contributions, substituting equation (15) in equation (19), the objective function of the government can be rewritten as:

$$
G(I)=\lambda\left[\frac{N}{1-\delta} \alpha^{1-\delta}\left(\frac{N+I}{H}\right)^{(1-\delta)(\alpha-1)}\right]+\frac{H}{1-\delta}(1-\alpha)^{1-\delta}\left(\frac{N+I}{H}\right)^{\alpha(1-\delta)}
$$

Maximization of equation (20) with respect to $I$ yields:

$$
I^{E}=\left[\lambda N\left(\frac{1-\alpha}{\alpha H}\right)^{\delta}\right]^{\frac{1}{1-\delta}}-N
$$

Clearly, $I^{E}>I^{C}$ as the lobby of entrepreneurs induces the government to deviate from the welfare maximizing level of immigration. With higher immigration, income is redistributed away from workers towards the entrepreneurs.

In this case, it is not a priori clear whether workers are hurt by the presence of the union. As the workers lose voice in the lobbying process, immigration level increases up to a point which may make it costly for them to eliminate the union.

Intuitively, the cost for workers of not being represented in the lobbying activity depends on how much the government weights contributions. The higher is this weight, the more distorted will be immigration policy in favor of entrepreneurs.

This intuition is formalized in the following:

Proposition 4 There exists a $\underline{\lambda} \in(0,1)$ such that, for any $\lambda<\underline{\lambda}$, workers benefit from the presence of the union.

\section{Proof. See Appendix}

Summing up, when the immigration level is determined by the political interaction between government and lobbies, workers may find it profitable to support the union 
in order to be more effective in the lobbying activity and avoid the implementation of excessively high levels of immigration. This happens when the bias of the government in favor of contributions is high enough or, in other words, when the government is not sufficiently benevolent.

Figure 1 shows the level of utility of workers as a function of $\lambda$.

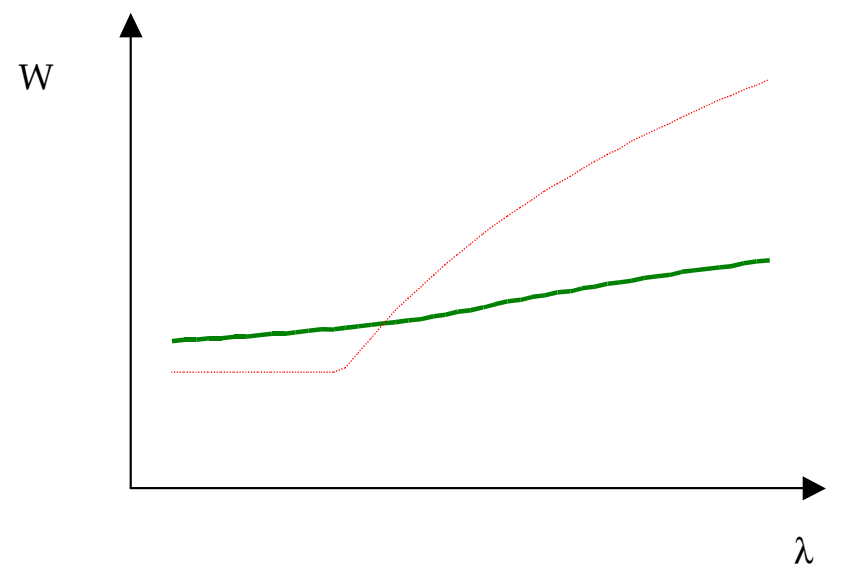

Figure 1: Welfare of workers as a function of $\lambda$

The thin (red) curve represents the expected utility of workers when there is no trade union. As explained in detail in appendix 2, the equation of this curve is given by:

$$
W_{w}= \begin{cases}\frac{1}{1-\delta} N^{\alpha} H^{1-\alpha} \alpha^{1-\delta \alpha}(1-\alpha)^{-\delta(1-\alpha)} \lambda^{\alpha-1} & \text { for } 1>\lambda>\left(\frac{\Gamma}{\Delta}\right)^{\sigma} \\ \underline{b}^{1-\delta} N \frac{1}{1-\delta} & \text { for } 0<\lambda \leq\left(\frac{\Gamma}{\Delta}\right)^{\sigma}\end{cases}
$$

The thick (green) curve represents the expected utility of workers when there is a trade union. Its equation is: $W_{w}^{u}=\left\{\begin{array}{l}\frac{1}{1-\delta} \alpha^{-\alpha \delta} N^{\alpha} H^{\frac{1}{\sigma}}(1-\alpha)^{\frac{-\delta}{\sigma}}\left(\left(\frac{1-\lambda^{\alpha}}{1-\lambda}\right) \Delta^{1-\sigma}+\alpha\left(1-\Delta^{1-\delta-\sigma}\right)\right) \quad \text { for } 1>\lambda>\Gamma^{\sigma} \\ \frac{1}{(1-\delta)(1-\lambda)}\left(\begin{array}{l}\Delta^{1-\sigma} \alpha^{1-\alpha \delta} N^{\alpha} H^{\frac{1}{\sigma}}(1-\alpha)^{\frac{-\delta}{\sigma}}\left(\frac{1}{\alpha}\right)+ \\ \left(1-\Delta^{-\sigma}-\lambda\right) \underline{b}^{1-\delta} N-H(1-\alpha)^{1-\delta}\left(\alpha^{\alpha \sigma(1-\delta)} \underline{b}^{-\alpha \sigma(1-\delta)}\right)\end{array}\right) \quad \text { for } 0 \leq \lambda \leq \Gamma^{\sigma}\end{array}\right.$

The intersection of the two curves defines $\underline{\lambda}$. As we know from Proposition 4, for any $\lambda>\underline{\lambda}$, the thin curve is above the thick curve and workers are better off with a competitive 
labor market and without contributing to the government. For any $\lambda<\underline{\lambda}$, the thin curve is below the thick curve and workers are better off with a unionized labor market and paying contributions to the government.

\section{Conclusion}

This paper develops a positive analysis of immigration policy when the labor market is noncompetitive due to the presence of a trade union and two distinct groups (entrepreneurs and workers) have conflicting interests over this policy.

Our main result is that the bargaining power of the union in the labor market induces a benevolent government to increase immigration above the level which would be optimal with a competitive labor market. The most important consequence is that workers end up being hurt by the union, while the entrepreneurs benefit from it. In the paper we provide a discussion of what are the features of the model that drive our results.

Notwithstanding this negative effect on workers' welfare, a political economy extension of the basic model, where the government is influenced by the lobbying activity of (lobbies of) workers and entrepreneurs, allows us to formalize a possible explanation of why workers may still be interested in supporting and financing the union. More specifically, we show that whenever the degree of benevolence of the government falls below a given threshold, workers are better off with the union.

Our research could be extended to incorporate a dynamic analysis which could shed light on the relationship between trade unions, immigration policy and economic growth. This analysis could be carried out using a OLG model, where the young (workers) oppose immigration while the old (owners of the firms) are in favor of it.

\section{References}

[1] AMEGASHIE, J. A. (2004), "A political economy model of immigration quotas", Economics of Governance, 5, 255-267. 
[2] BELLETTINI, G. and BERTI CERONI, C. (2004), "A general equilibrium model of the trade union", Department of Economics, University of Bologna, mimeo.

[3] Bellettini, G. and OtTAViAnO, G. (2005), "Special interests and technological change", Review of Economic Studies, 72, 43-56.

[4] BOOTH, A. L. (1995), "The Economics of the Trade Union", Cambridge: Cambridge University Press.

[5] BERNHEIM, B.D. and WHINSTON, M.D. (1986), "Menu auctions, resource allocation, and economic influence", Quarterly Journal of Economics, 101, 1-31.

[6] DIXIT, A.K., GROSSMAN, G. and HELPMAN, E. (1997), "Common agency and coordination: General theory and application to government policy making", Journal of Political Economy, 105, 753-769.

[7] EPSTEIN, G.S. and NITZAN, S. (2002), "The struggle over migration policy", mimeo.

[8] FARBER, H. S. (1986), "The analysis of union behavior", in O. Ashenfelter and R. Layard eds, Handbook of Labor Economics, Vol. II, Amsterdam: North-Holland.

[9] FREEMAN G. P. (2000), "Political science and comparative immigration politics", University of Texas at Austin, mimeo.

[10] FUEST, C. and THUM, M. (2001), "Immigration and skill formation in unionised labour markets", European Journal of Political Economy, 17, 557-573.

[11] GROSSMAn, G. and HELPMAN, E. (1994), "Protection for sale", American Economic Review, 84, 833-850.

[12] HANSON, G., SCHEVE, K., SLAUGHTER M. and A. SPILIMBERGO (2002), "Immigration and the U.S. Economy: Labor-Market Impacts, Illegal Entry, and Policy Choices", in Boeri T., Hanson, G. and B. McCormick (eds.), Immigration Policy and the Welfare State, Oxford University Press. 
[13] HATTON, T.J. and J.G. WILLIAMSON (2004), "International migration in the longrun: Positive selection, negative selection and policy", NBER Working Paper no. 10529 .

[14] IRMEN, A. and B. WIGGER (2003), "Trade union objectives and economic growth", FinanzArchiv, 59(1), 49-67.

[15] O'ROURKE K. and R. SINNOTT (2004), "The determinants of individual attitudes towards immigration", Trinity College Dublin, mimeo.

[16] PERSSON, T. (1998), "Economic policy and special interest politics", Economic Journal, 108, 310-327.

[17] SCHMIDT, C.M., STILZ, A. and K.F. ZIMMERMANN (1994), "Mass migration, unions and government intervention", Journal of Public Economics, 55, 185-201.

\section{APPENDIX 1}

\section{Proof of Proposition 3}

(i) Using equations (6) and (15), the maximization problem of the government can be rewritten (in an interior equilibrium) as:

$$
I=\arg \max \sum_{j \in\{e, w\}} V_{j}(I)
$$

which yields $I=I^{*}$.

(ii) As explained in Grossman and Helpman [11], equilibrium contributions are given by:

$$
C_{w}^{*}=V_{e}\left(I^{-w}\right)-V_{e}\left(I^{*}\right)+\frac{\lambda}{1-\lambda}\left[W\left(I^{-w}\right)-W\left(I^{*}\right)\right]
$$

where $I^{-w}$ is the solution to (18) when only entrepreneurs offer contributions. Simple calculations show that $I^{-w}=\left[\lambda N\left(\frac{1-\alpha}{\alpha H}\right)^{\delta}\right]^{\frac{1}{1-\delta}}-N$. The wage level when $I=I^{-w}$ is given by $w\left(I^{-w}\right)=\alpha\left(\frac{N+I^{-w}}{H}\right)^{\frac{-1}{\sigma}}$ so that for $\lambda=\Gamma^{\sigma}$ we get $w\left(I^{-w}\right)=\underline{b}$. Thus, for any $\lambda<\Gamma^{\sigma}$, $I^{-w}$ is fixed and equal to $\left[\Gamma^{\sigma} N\left(\frac{1-\alpha}{\alpha H}\right)^{\delta}\right]^{\frac{1}{1-\delta}}$. Some additional algebra yields the expression for $C_{w}^{*}$ which was given in the Proposition. 
(iii) Similarly to (ii), equilibrium contributions for the lobby of entrepreneurs are given by:

$$
C_{e}^{*}=V_{w}\left(I^{-e}\right)-V_{w}\left(I^{*}\right)+\frac{\lambda}{1-\lambda}\left[W\left(I^{-e}\right)-W\left(I^{*}\right)\right]
$$

where $I^{-e}$ is the solution to (18) when only workers offer contributions. It can be easily verified that $I^{-w}=\left[\lambda^{-1} \Delta^{-\delta \sigma} N\left(\frac{1-\alpha}{\alpha H}\right)^{\delta}\right]^{\frac{1}{1-\delta}}$ so that we have $w\left(I^{-e}\right)=\underline{b}$ when $\lambda=\Gamma^{-\sigma}$. Thus, for any $\lambda<\Gamma^{-\sigma}, I^{-e}$ is fixed and equal to $\left[\Gamma^{\sigma} \Delta^{-\delta \sigma} N\left(\frac{1-\alpha}{\alpha H}\right)^{\delta}\right]^{\frac{1}{1-\delta}}$. Additional algebra yields the expression for $C_{e}^{*}$ which was given in the Proposition.

\section{APPENDIX 2}

\section{Proof of Proposition 4}

First of all, let $W_{w}^{u}$ denote the welfare of workers with the union (that is, when both lobbies contribute) and $W_{w}$ the welfare of workers without the union (that is, when only the lobby of entrepreneurs effectively contribute). Then:

$$
W_{w}=\frac{1}{1-\delta} N^{\alpha} H^{1-\alpha} \alpha^{1-\delta \alpha}(1-\alpha)^{-\delta(1-\alpha)} \lambda^{\alpha-1}
$$

which is an increasing and strictly concave function of $\lambda$. Notice that when $\lambda=\left(\frac{1-\Delta^{-\sigma}}{1-\Delta^{-\sigma-\delta+1}}\right)^{\sigma}=$ $\frac{\Gamma^{\sigma}}{\Delta^{\sigma}}$ the wage rate is equal to $\underline{b}$ so that we can write:

$$
W_{w}=\left\{\begin{array}{cl}
\frac{1}{1-\delta} N^{\alpha} H^{1-\alpha} \alpha^{1-\delta \alpha}(1-\alpha)^{-\delta(1-\alpha)} \lambda^{\alpha-1} & \text { for } 1>\lambda>\frac{\Gamma^{\sigma}}{\Delta^{\sigma}} \\
\underline{b}^{1-\delta} N \frac{1}{1-\delta} & \text { for } 0<\lambda \leq \frac{\Gamma^{\sigma}}{\Delta^{\sigma}}
\end{array}\right.
$$

When the union exists, in the computation of the welfare of workers we must take into account the contribution paid to the government. Therefore, we can write:

$$
W_{w}^{u}=\frac{1}{1-\delta} \alpha^{-\alpha \delta} N^{\alpha} H^{\frac{1}{\sigma}}(1-\alpha)^{\frac{-\delta}{\sigma}}\left(\left(\frac{1-\lambda^{\alpha}}{1-\lambda}\right) \Delta^{1-\sigma}+\alpha\left(1-\Delta^{1-\delta-\sigma}\right)\right)
$$

which is an increasing and strictly concave function of $\lambda$. However, it should be noted (see Appendix 1) that, when $\lambda=\Gamma^{\sigma}$, we have that $w\left(I^{-w}\right)=\underline{b}$, so that, for $\lambda<\Gamma^{\sigma}, I^{-w}$ becomes fixed. Thus, we can write:

$$
W_{w}^{u}=\left\{\begin{array}{c}
\frac{1}{1-\delta} \alpha^{-\alpha \delta} N^{\alpha} H^{\frac{1}{\sigma}}(1-\alpha)^{\frac{-\delta}{\sigma}}\left(\left(\frac{1-\lambda^{\alpha}}{1-\lambda}\right) \Delta^{1-\sigma}+\alpha\left(1-\Delta^{1-\delta-\sigma}\right)\right) \text { for } 1>\lambda>\Gamma^{\sigma} \\
\frac{1}{\Delta^{1-\sigma} \alpha^{-\alpha \delta} N^{\alpha} H^{\frac{1}{\sigma}}(1-\alpha)^{\frac{-\delta}{\sigma}}+}\left(\begin{array}{c}
1-\delta)(1-\lambda) \\
\left(1-\Delta^{-\sigma}-\lambda\right) \underline{b}^{1-\delta} N-H(1-\alpha)^{1-\delta}\left(\alpha^{\alpha \sigma(1-\delta)} \underline{b}^{-\alpha \sigma(1-\delta)}\right)
\end{array}\right) \text { for } 0 \leq \lambda \leq \Gamma^{\sigma}
\end{array}\right.
$$


After some algebra, it can be shown that, for $0<\lambda \leq \Gamma^{\sigma}, W_{w}^{u}$ is an increasing and strictly convex function of $\lambda$. Notice also that:

$$
\lim _{\lambda \rightarrow 1} W_{w}^{u}=\frac{1}{1-\delta}\left(\Delta^{1-\sigma} \alpha^{1-\alpha \delta} N^{\alpha} H^{\frac{1}{\sigma}}(1-\alpha)^{\frac{-\delta}{\sigma}}+\left(1-\Delta^{-\sigma}\right) \underline{b}^{1-\delta} N\right)
$$

Let us now prove that $W_{w}^{u}=W_{w}$ for only one $\lambda \in(0,1)$.

First of all, we have that $\lim _{\lambda \rightarrow 0} W_{w}^{u}>\lim _{\lambda \rightarrow 0} W_{w}$ (after some algebra) and $\lim _{\lambda \rightarrow 1} W_{w}^{u}<$ $\lim _{\lambda \rightarrow 1} W_{w}$ (by Proposition 1) so that at least one $\lambda$ for which $W_{w}^{u}=W_{w}$ exists. To show that it is unique, we can use the fact that $W_{w}^{u}$ is strictly convex for $\lambda \leq \Gamma^{\sigma}$, while $W_{w}$ is concave, so that the two functions can intersect at most once between 0 and $\Gamma^{\sigma}$. If $W_{w}^{u}$ and $W_{w}$ intersect between 0 and $\Gamma^{\sigma}$, then this is the only intersection point since in this case, for $\lambda>\Gamma^{\sigma}, W_{w}^{u}$ must be strictly smaller than $W_{w}$ (notice that for any $\lambda>\Gamma^{\sigma}$ the relevant expression of $W_{w}^{u}$ is always smaller of the function in second row of 28 , which has already crossed $\left.W_{w}\right)$.

If instead $W_{w}^{u}$ and $W_{w}$ do not intersect between 0 and $\Gamma^{\sigma}$, their intersection point is unique since, for $\lambda>\Gamma^{\sigma}, W_{w}^{u}=W_{w} \Leftrightarrow \Delta^{-\alpha \sigma}=\alpha(\lambda-1)\left(1-\Delta^{1-\delta-\sigma}\right)+\lambda^{\alpha} \Delta^{-\alpha \sigma}+$ $\alpha \lambda^{\alpha-1}(1-\lambda)$, which is satisfied for only one $\lambda \in(0,1)$.

\section{APPENDIX 3}

\section{An efficient bargaining model}

Consider the efficient barganing model developed by Fuest and Thum. Assume that $\gamma H$ firms are unionized and pay a wage rate denoted by $w$ while the remaining $(1-\gamma) H$ are not unionized and pay $w^{c}$. It can be shown that in this framework all firms employ the same amount of workers $(N+I) / H$ and $w=\Delta w^{c}$ where $w^{c}=\alpha\left(\frac{N+I}{H}\right)^{\alpha-1}$ and $\Delta=1+\beta \frac{1-\alpha}{\alpha}$ where $\beta$ is the barganing power of unions.

Given these solutions, we can find the optimal level of immigration, which is given by:

$$
I^{G}=\frac{\alpha^{\frac{\delta}{\delta-1}}(1-\alpha)^{\frac{1}{1-\delta}} N^{\frac{1}{1-\delta}}\left[\gamma \Delta^{1-\delta}+(1-\gamma)\right]^{\frac{1}{1-\delta}}}{\left[\gamma(1-\Delta \alpha)^{1-\delta}+(1-\gamma)(1-\alpha)^{1-\delta}\right]^{\frac{1}{1-\delta}}} H^{\frac{\delta}{\delta-1}}-N
$$

Using equation (30), we can conclude that the higher is $\Delta$ the higher is the level of immigration chosen by the government. Moreover, it can also be shown that, when $I^{G}$ is given by equation (30), both workers and entrepreneurs are better off when $\Delta=1$, 
although, for a given level of $I$, workers would benefit from an increase in their barganing power. 


\title{
CESifo Working Paper Series
}

\author{
(for full list see www.cesifo.de)
}

1358 M. Hashem Pesaran and Paolo Zaffaroni, Model Averaging and Value-at-Risk Based Evaluation of Large Multi Asset Volatility Models for Risk Management, December 2004

1359 Fwu-Ranq Chang, Optimal Growth and Impatience: A Phase Diagram Analysis, December 2004

1360 Elise S. Brezis and François Crouzet, The Role of Higher Education Institutions: Recruitment of Elites and Economic Growth, December 2004

1361 B. Gabriela Mundaca and Jon Strand, A Risk Allocation Approach to Optimal Exchange Rate Policy, December 2004

1362 Christa Hainz, Quality of Institutions, Credit Markets and Bankruptcy, December 2004

1363 Jerome L. Stein, Optimal Debt and Equilibrium Exchange Rates in a Stochastic Environment: an Overview, December 2004

1364 Frank Heinemann, Rosemarie Nagel and Peter Ockenfels, Measuring Strategic Uncertainty in Coordination Games, December 2004

1365 José Luis Moraga-González and Jean-Marie Viaene, Anti-Dumping, Intra-Industry Trade and Quality Reversals, December 2004

1366 Harry Grubert, Tax Credits, Source Rules, Trade and Electronic Commerce: Behavioral Margins and the Design of International Tax Systems, December 2004

1367 Hans-Werner Sinn, EU Enlargement, Migration and the New Constitution, December 2004

1368 Josef Falkinger, Noncooperative Support of Public Norm Enforcement in Large Societies, December 2004

1369 Panu Poutvaara, Public Education in an Integrated Europe: Studying to Migrate and Teaching to Stay?, December 2004

1370 András Simonovits, Designing Benefit Rules for Flexible Retirement with or without Redistribution, December 2004

1371 Antonis Adam, Macroeconomic Effects of Social Security Privatization in a Small Unionized Economy, December 2004

1372 Andrew Hughes Hallett, Post-Thatcher Fiscal Strategies in the U.K.: An Interpretation, December 2004 
1373 Hendrik Hakenes and Martin Peitz, Umbrella Branding and the Provision of Quality, December 2004

1374 Sascha O. Becker, Karolina Ekholm, Robert Jäckle and Marc-Andreas Mündler, Location Choice and Employment Decisions: A Comparison of German and Swedish Multinationals, January 2005

1375 Christian Gollier, The Consumption-Based Determinants of the Term Structure of Discount Rates, January 2005

1376 Giovanni Di Bartolomeo, Jacob Engwerda, Joseph Plasmans, Bas van Aarle and Tomasz Michalak, Macroeconomic Stabilization Policies in the EMU: Spillovers, Asymmetries, and Institutions, January 2005

1377 Luis H. R. Alvarez and Erkki Koskela, Progressive Taxation and Irreversible Investment under Uncertainty, January 2005

1378 Theodore C. Bergstrom and John L. Hartman, Demographics and the Political Sustainability of Pay-as-you-go Social Security, January 2005

1379 Bruno S. Frey and Margit Osterloh, Yes, Managers Should Be Paid Like Bureaucrats, January 2005

1380 Oliver Hülsewig, Eric Mayer and Timo Wollmershäuser, Bank Loan Supply and Monetary Policy Transmission in Germany: An Assessment Based on Matching Impulse Responses, January 2005

1381 Alessandro Balestrino and Umberto Galmarini, On the Redistributive Properties of Presumptive Taxation, January 2005

1382 Christian Gollier, Optimal Illusions and Decisions under Risk, January 2005

1383 Daniel Mejía and Marc St-Pierre, Unequal Opportunities and Human Capital Formation, January 2005

1384 Luis H. R. Alvarez and Erkki Koskela, Optimal Harvesting under Resource Stock and Price Uncertainty, January 2005

1385 Ruslan Lukach, Peter M. Kort and Joseph Plasmans, Optimal R\&D Investment Strategies with Quantity Competition under the Threat of Superior Entry, January 2005

1386 Alfred Greiner, Uwe Koeller and Willi Semmler, Testing Sustainability of German Fiscal Policy. Evidence for the Period 1960 - 2003, January 2005

1387 Gebhard Kirchgässner and Tobias Schulz, Expected Closeness or Mobilisation: Why Do Voters Go to the Polls? Empirical Results for Switzerland, 1981 - 1999, January 2005

1388 Emanuele Bacchiocchi and Alessandro Missale, Managing Debt Stability, January 2005 
1389 Assar Lindbeck and Dirk Niepelt, Improving the SGP: Taxes and Delegation rather than Fines, January 2005

1390 James J. Heckman and Dimitriy V. Masterov, Skill Policies for Scotland, January 2005

1391 Emma Galli \& Fabio Padovano, Sustainability and Determinants of Italian Public Deficits before and after Maastricht, January 2005

1392 Angel de la Fuente and Juan Francisco Jimeno, The Private and Fiscal Returns to Schooling and the Effect of Public Policies on Private Incentives to Invest in Education: A General Framework and Some Results for the EU, January 2005

1393 Juan C. Conesa and Carlos Garriga, Optimal Response to a Demographic Shock, January 2005

1394 Christian Gollier, Optimal Portfolio Management for Individual Pension Plans, February 2005

1395 Ruslan Lukach, Joseph Plasmans and Peter M. Kort, Innovation Strategies in a Competitive Dynamic Setting, February 2005

1396 Gebhard Kirchgässner, (Why) Are Economists Different?, February 2005

1397 Marko Köthenbürger, Panu Poutvaara and Paola Profeta, Why are More Redistributive Social Security Systems Smaller? A Median Voter Approach, February 2005

1398 Gabrielle Demange, Free Choice of Unfunded Systems: A First Assessment, February 2005

1399 Carlos Fonseca Marinheiro, Sustainability of Portuguese Fiscal Policy in Historical Perspective, February 2005

1400 Roel M. W. J. Beetsma and Koen Vermeylen, The Effect of Monetary Unification on Public Debt and its Real Return, February 2005

1401 Frank Asche, Petter Osmundsen and Maria Sandsmark, Is It All Oil?, February 2005

1402 Giacomo Corneo, Media Capture in a Democracy: The Role of Wealth Concentration, February 2005

1403 A. Lans Bovenberg and Thijs Knaap, Ageing, Funded Pensions and the Dutch Economy, February 2005

1404 Thiess Büttner, The Incentive Effect of Fiscal Equalization Transfers on Tax Policy, February 2005

1405 Luisa Fuster, Ayşe İmrohoroğlu and Selahattin İmrohoroğlu, Personal Security Accounts and Mandatory Annuitization in a Dynastic Framework, February 2005 
1406 Peter Claeys, Policy Mix and Debt Sustainability: Evidence from Fiscal Policy Rules, February 2005

1407 James M. Malcomson, Supplier Discretion over Provision: Theory and an Application to Medical Care, February 2005

1408 Thorvaldur Gylfason, Interview with Assar Lindbeck, February 2005

1409 Christian Gollier, Some Aspects of the Economics of Catastrophe Risk Insurance, February 2005

1410 Gebhard Kirchgässner, The Weak Rationality Principle in Economics, February 2005

1411 Carlos José Fonseca Marinheiro, Has the Stability and Growth Pact Stabilised? Evidence from a Panel of 12 European Countries and Some Implications for the Reform of the Pact, February 2005

1412 Petter Osmundsen, Frank Asche, Bård Misund and Klaus Mohn, Valuation of International Oil Companies -The RoACE Era, February 2005

1413 Gil S. Epstein and Shmuel Nitzan, Lobbying and Compromise, February 2005

1414 Marcel F. M. Canoy, Jan C. van Ours and Frederick van der Ploeg, The Economics of Books, February 2005

1415 Eric A. Hanushek and Ludger Wößmann, Does Educational Tracking Affect Performance and Inequality? Differences-in-Differences Evidence across Countries, February 2005

1416 George Kapetanios and M. Hashem Pesaran, Alternative Approaches to Estimation and Inference in Large Multifactor Panels: Small Sample Results with an Application to Modelling of Asset Returns, February 2005

1417 Samuel Mühlemann, Jürg Schweri, Rainer Winkelmann and Stefan C. Wolter, A Structural Model of Demand for Apprentices. February 2005

1418 Giorgio Brunello and Lorenzo Rocco, Educational Standards in Private and Public Schools, February 2005

1419 Alex Bryson, Lorenzo Cappellari and Claudio Lucifora, Why so Unhappy? The Effects of Unionisation on Job Satisfaction, March 2005

1420 Annalisa Luporini, Relative Performance Evaluation in a Multi-Plant Firm, March 2005

1421 Giorgio Bellettini and Carlotta Berti Ceroni, When the Union Hurts the Workers: A Positive Analysis of Immigration Policy, March 2005 